\title{
Оценка оптимальной структуры капитала компаний ОАО «Уралкалий» и Kali\&Salz AG
}

\author{
Анюхина И.М., Иванинский И.О., Катаева Е.В., Озорнина О.В., \\ Серебрянский Д.В. ${ }^{53}$, Шмидт-Рост М. ${ }^{54}$.
}

Статья имеет практический характер: в ней авторы детально осветили поэтапныий механизм оценки оптимальной структуры капитала российской химической компании ОАО «Уралкалий», а также обозначили основные проблемы, с которыми столкнулись при применении подходов на развивающемся рынке. Были использованы модели затрат на капитал, операчионной прибыли и скорректированной приведенной стоимости. Кроме того, авторы провели сравнение полученных результатов с оптимальной структурой капитала немечкого конкурента Kali\&Salz AG u выдвинули гипотезы объяснения выявленных различий. Также авторы рассчитали требуемую доходность по собственному капиталу ОАО «Уралкалий» по локальной, глобальной и гибридной моделям оченки капитальньх активов (САРМ), обратив отдельное внимание на преимущества $и$ недостатки каждого из методов.

Наиболее подходящим методом для оценки требуемой доходности по собственному капиталу ОАО «Уралкалий», с точки зрения авторов данной статьи, является гибридная модель САРМ. Основной недостаток локальной модели САРМ - это ненадежность данных по российскому фондовому рынку для расчета премии за риск и бэта; недостаток глобальной САРМ - акции компании обращаются на международном рынке (Лондонской фондовой бирже) только с кония 2007 года, поэтому применить метод не представляется возможным.

ОАО «Уралкалий» на момент исследования (31.12.07 был выбран как момент исследования, для того чтобы проследить динамику в 2008 году) имеет схожую структуру капитала с конкурентами: отношение совокупных обязательств к активам по балансовой стоимости равно 36,74\%. Модель затрат на капитал (WАCC) показала, что оптимальный уровень обязательств, минимизирующий затратьл на капитал, лежит в интервале от 30 до 40\%. Согласно модели скорректированной приведенной стоимости (APV), учитывающей выгоды от налогового шита и издержки финансовой неустойчивости, максимум стоимости ОАО «Уралкалий» достигается при уровне отношения обязательств к активам в 50\%. Однако необходимо отметить, что АРV в данном исследовании обладает большим недостатком, связанным с сомнительной статистической значимостью стандартной ошибки прибыли до выплаты процентов и налогов (ЕВIT) на основе всего семи исторических наблюдений (за 2001-2007 годы). Значит, ОАО «Уралкалий» на конеи 2007 года имело структуру капитала, очень близкую к оптимальной. В 2008 году анализируемьй показатель структуры капитала несколько снизился - до 35,2\%, это значение лежит в оптимальном интервале, таким образом максимизируя стоимость.

На конец 2007 года немеикий конкурент Kali\&Salz AG обладал обязательствами, более чем вдвое превышающими оптимальное соотношение; оптимум соответствует интервалу от 20 до 30\% (аналогично были использованы модели WАCC, операционной прибыли, АРV). Сравнение очененной оптимальной структуры капитала компаний показало, что российской компании следует занимать несколько больще в оптимальном состоянии по сравнению с немецкой - ввиду большей требуемой доходности по собственному капиталу при схожих требуемых доходностях по заемному капиталу (с точностью до суверенного

\footnotetext{
${ }^{53}$ Стажеры-исследователи научно-учебной лаборатории корпоративных финансов ГУ-ВШЭ.

${ }^{54}$ Студент по обмену из университета Гумбольдта (Берлин, Германия), стажер-исследователь научно-учебной лаборатории корпоративных финансов ГУ ВШЭ.
} 
риска).

JEL: G12, G32

Ключевые слова: оптимальная структура капитала, затраты на капитал

\section{Введение}

Целью данной работы является применение современных подходов теории корпоративных финансов для оценки оптимальной структуры капитала российской компании. Перед нами стояло две задачи: во-первых, оценить оптимальную структуру капитала корпорации ОАО «Уралкалий» и при этом обсудить применимость тех или иных подходов для российских компаний; во-вторых, сравнить ее с оптимальной структурой капитала немецкого конкурента Kali\&Salz AG и выделить межстрановые и межфирменные различия.

При выборе объекта исследования к российским компаниям предъявлялись следующие требования: компания должна быть негосударственной (чтобы нивелировать все эффекты, связанные с государственной собственностью); иметь длительную историю котировок акций на фондовой бирже (чтобы рассчитать бэту и получить корректные оценки требуемой доходности по собственному капиталу); иметь конкурента в Германии как по подотрасли, так и по размерам (обороту, активам). Таким образом, выбрав ОАО «Уралкалий» и конкурента Kali\&Salz AG, мы сформулировали следующую гипотезу для проверки: имеет ли компания структуру капитала, максимизирующую ее стоимость, и движется ли в направлении достижения оптимума?

\section{1. Основные характеристики ОАО «Уралкалий»}

- Специализация - производство калийных удобрений.

- Запасы сильвинита (сырья для производства хлористого калия) - $22 \%$ от общемировых запасов.

- Выпускает около $11 \%$ мирового объема калийных удобрений.

- Экспортирует свыше 90\% готовой продукции.

- Акционеры: 65,5\% - Д. Рыболовлев; остальное - free float.

- Котируется на РТС с 2002 года.

- $\quad$ IPO на LSE проведено 10.2007 - 270,85 млн акций (12,75\% от общего числа) на сумму $\$ 947,97$ млн. 


\section{Диаграмма 1}

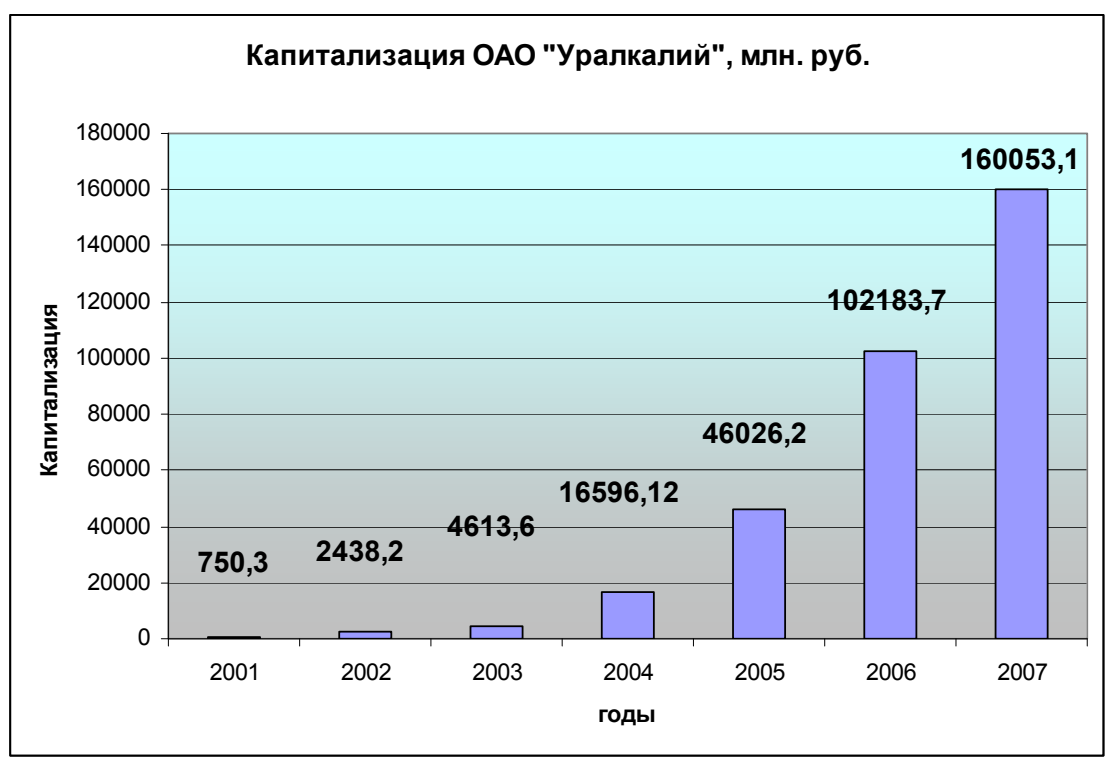

ОАО «Уралкалий» является одной из самых динамичных компаний России (среднегодовой темп роста капитализации за 2001-2007 годы составляет 215,14\%); ей удалось одной из первых выйти на РТС и Лондонскую фондовую биржу (LSE). Несомненно, важным фактором является наличие уникальных запасов сильвинита, однако это не достаточное условие достигнутых результатов. С нашей точки зрения, более важно умелое корпоративное управление, направленное на максимизацию стоимости компании, благосостояние ее акционеров. В этой связи интересно проанализировать, максимизирует ли текущая структура капитала стоимость компании.

\section{2. Текущая структура капитала}

Мы проанализировали текущую структуру капитала ОАО «Уралкалий» на 31.12.07, используя консолидированную финансовую отчетность группы компании по стандартам МСФО (источник: www.uralkali.ru).

Выбор периода наблюдения объясняется тем, что целью является оценка оптимальной структуры капитала и выработка рекомендаций, а также анализ изменения структуры капитала после периода наблюдения, то есть в 2008 году. Кроме того, мы не выбрали более поздние периоды наблюдения, так как отчетность, публикуемая в ежеквартальных отчетах эмитента, не является консолидированной. Наконец, кризисные явления, проступавшие в России еще с весны-лета 2008 года, могли бы исказить картину, так как привели бы к резкому росту требуемой доходности по заемному капиталу и снижению доходов компании.

В таблице 1 представлены основные показатели структуры капитала ОАО «Уралкалий» на 31.12.07. 
Таблица 1

\begin{tabular}{|c|c|c|}
\hline Показатель & Формула расчета & $\begin{array}{c}\text { Значение, } \\
\text { \% }\end{array}$ \\
\hline Short term debt ratio & $\begin{array}{l}\text { Отношение краткосрочного процентного долга компании к сумме } \\
\text { ее совокупного долга и балансовой стоимости ее акционерного } \\
\text { капитала }\end{array}$ & 11,66 \\
\hline Long term debt ratio & $\begin{array}{l}\text { Отношение долгосрочного процентного долга компании к сумме ее } \\
\text { совокупного долга и балансовой стоимости ее акционерного } \\
\text { капитала }\end{array}$ & 16,26 \\
\hline Total debt ratio & $\begin{array}{l}\text { Отношение долгосрочного и краткосрочного процентных долгов } \\
\text { компании к сумме ее совокупного долга и балансовой стоимости ее } \\
\text { акционерного капитала }\end{array}$ & 27,92 \\
\hline $\begin{array}{l}\text { Market value } \\
\text { short term debt ratio }\end{array}$ & $\begin{array}{l}\text { Отношение краткосрочного процентного долга компании к сумме } \\
\text { ее совокупного долга и рыночной стоимости ее акционерного } \\
\text { капитала }\end{array}$ & 2,65 \\
\hline $\begin{array}{l}\text { Market value } \\
\text { long term debt ratio }\end{array}$ & $\begin{array}{l}\text { Отношение долгосрочного процентного долга компании к сумме ее } \\
\text { совокупного долга и рыночной стоимости еe акционерного } \\
\text { капитала }\end{array}$ & 3,69 \\
\hline $\begin{array}{l}\text { Market value } \\
\text { total debt ratio }\end{array}$ & $\begin{array}{l}\text { Отношение совокупного процентного долга компании к сумме ее } \\
\text { совокупного долга и рыночной стоимости ее акционерного } \\
\text { капитала }\end{array}$ & 6,34 \\
\hline $\begin{array}{l}\text { Book value } \\
\text { short term debt ratio }\end{array}$ & $\begin{array}{l}\text { Отношение краткосрочных обязательств компании к балансовой } \\
\text { стоимости ее активов }\end{array}$ & 18,80 \\
\hline $\begin{array}{l}\text { Book value } \\
\text { long term debt ratio }\end{array}$ & $\begin{array}{l}\text { Отношение долгосрочных обязательств компании к балансовой } \\
\text { стоимости ее активов }\end{array}$ & 17,94 \\
\hline $\begin{array}{l}\text { Book value } \\
\text { total debt ratio }\end{array}$ & $\begin{array}{l}\text { Отношение совокупных обязательств компании } \quad \text { к балансовой } \\
\text { стоимости ее активов }\end{array}$ & 36,74 \\
\hline
\end{tabular}

\section{Диаграмма 2}

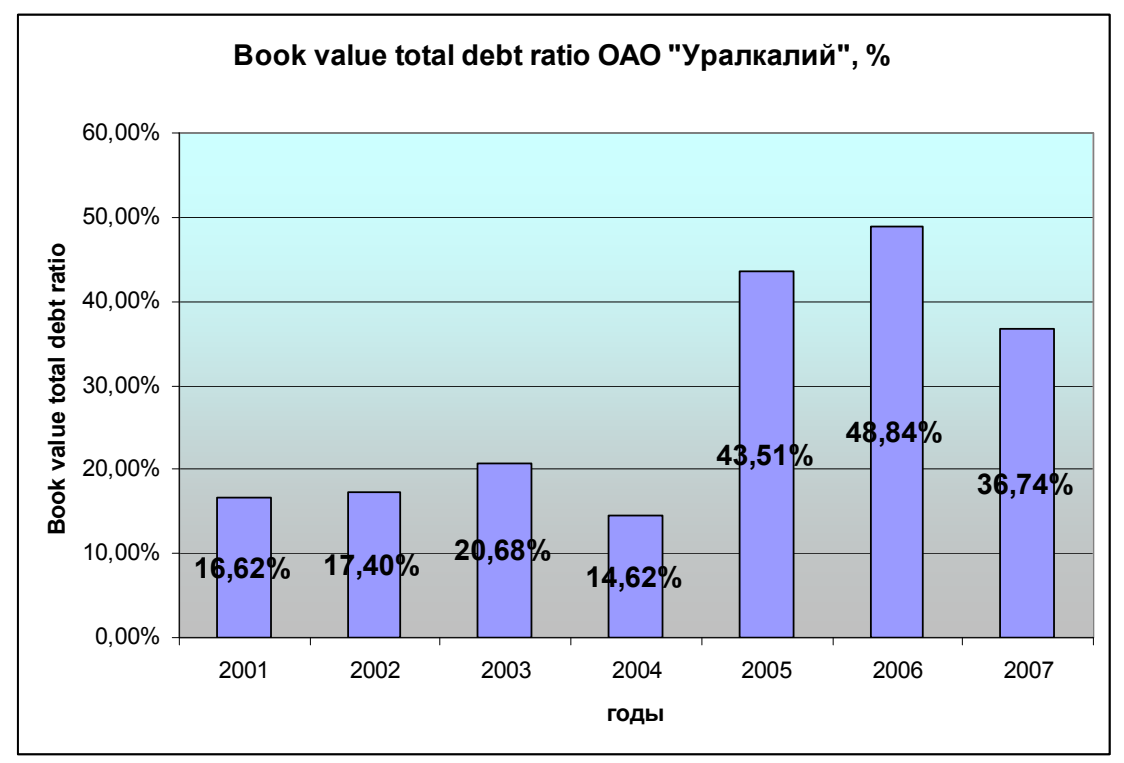

Динамика показателя отношения совокупных обязательств к активам ОАО «Уралкалий» за 2001-2007 годы (представленная на диаграмме 2) показывает, что в 2007 году по сравнению с 2001-м показатель увеличился в 2,2 раза. С 2006 года показатель снизился с 48,84 до $36,74 \%$ - на $25 \%$ - за счет размещения в октябре 2007 года на LSE $12,75 \%$ акций.

\section{Выпуск \#4(8), 2008


Далее мы применим основные модели оптимальной структуры капитала, для того чтобы понять, максимизирует ли текущая структура капитала внутреннюю стоимость компании, а также рекомендовать оптимальное соотношение собственного и заемного капитала в компании.

\section{3. Расчет требуемой доходности по собственному капиталу}

\section{1. Локальная модель оценки капитальных активов (local CAPM) [Шарп, 1964; Линтнер,} 1965]

В этом методе используются исторические значения премии за рыночный риск, как разницы между доходностью рыночного портфеля и безрисковой ставкой на финансовом рынке той страны, где обращается исследуемая ценная бумага.

\section{$R_{e}=R_{f}+\beta\left(R_{m}-R_{f}\right)$}

Для оценки премии за рыночный риск используются исторические значения. Суть подхода оценки на основе исторических данных проста: фактическая доходность, приносимая акциями в долгосрочном периоде, оценивается и сравнивается с фактической доходностью, создаваемыми свободными от риска дефолта ценными бумагами. Понятно, что такой подход хорошо работает для тех стран, где фондовый рынок крупный и диверсифицированный, а также есть длительная история доходностей ценных бумаг. Но к сожалению, в силу вышеназванных причин для развивающихся стран можно получить лишенные смысла оценки премий за риск методом local CAPM.

Мы считаем, что на фондовом рынке России существует достаточно короткая история доходностей ценных бумаг, так как первая из фондовых бирж РТС заработала в 1998 году. Говорить о полноценном начале работы финансового рынка России можно только после 2000 года. Несмотря на данный недостаток модели local CAPM, она активно применяется для оценки требуемой доходности собственного капитала.

Шаг 1. В качестве безрискового актива выбираем долгосрочную государственную ценную бумагу: еврооблигации Россия-2030. На 31.12.07 доходность составляла 5,36\%. ${ }^{55}$ Так как еврооблигации выпущены в долларах США, мы должны скорректировать значение на разницу в инфляциях в России $(11,9 \%)$ и США $(4,1 \%)$ по итогам 2007 года. $R_{f}=5,36 \% *(111,9 \% / 104,1 \%)=5,76 \%$

Шаг 2. Для расчета бэты воспользуемся следующей формулой: $\beta=\operatorname{Cov}\left(R_{m}, R_{\theta}\right) / \operatorname{Var}\left(R_{m}\right)$.

В качестве рыночного портфеля выбираем индекс РТС. Стандартный для расчетов бэта временной горизонт - 5 лет. Рассчитываем ежедневные доходности рыночного индекса и ежедневные доходности акции «Уралкалия» за 2002-2007 годы. Проблему, связанную с отсутствием котировок акций за некоторые дни, решаем с помощью расчета средних между соседними значениями. $\beta=0,596$ - акции «Уралкалий» менее рискованны, чем рынок.

Шаг 3. Расчет рыночной премии за риск осуществляем на основе исторических ежедневных котировок рыночного индекса РТС и еврооблигации Россия-2030 за 2000-2007 годы. Дилемма о длине используемого временного периода не возникает, мы используем все доступные данные, т.е. с 2000 года, когда была выпущена еврооблигация Россия-2030. Однако вторая дилемма, касающаяся выбора метода расчета средней, остается: арифметическая или геометрическая? Как правило, используют среднеарифметическую оценку, потому что если ежедневные доходы не коррелируют во времени, а нам интересна оценка на будущее, то среднеарифметическая оценка является непредвзятой. Market risk premium $=11 \%$.

Шаг 4. $R_{e}=5,76 \%+0,6 * 11 \%=12,36 \%$.

Мы уже упомянули о проблеме малой длительности котировок ценных бумаг, поэтому

\footnotetext{
${ }^{55}$ Источник: http://www.sbrf.ru/common/img/uploaded/analytics/2008/Sberbank280108.pdf

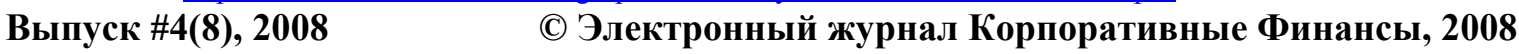


перейдем к расчету требуемой доходности по собственному капиталу методом Global CAPM.

\section{2. Глобальная модель оценки капитальных активов (Global CAPM) [Штульц, 1999]}

Так как надежную оценку премии за риск на российском финансовом рынке получить трудно, практически невозможно, то рассчитывают значения премии за риск для рынка США, фондовый рынок которого функционирует с 1928 года, и добавляют премию за страновой риск (суверенная премия). Глобальная модель предполагает, что компания обращается на международном рынке, для того чтобы корректно рассчитать бэту относительно финансового рынка США или другого финансового рынка с намного более длительной историей. Может показаться, что «Уралкалий» - одна из немногих частных компаний России, для расчета требуемой доходности которой можно применить глобальную модель CAPM, так как компания котируется на LSE. Однако «Уралкалий» вышел на международный рынок только в октябре 2007 года. Следовательно, для расчета бэты в нашем распоряжении окажутся значения лишь за 3 месяца, чего однозначно недостаточно.

\section{3. Гибридная модель оценки капитальных активов (Hybrid CAPM) [Дамодаран, 2004]}

Справиться с недостатком недолгой истории котировок «Уралкалия» на международном финансовом рынке, при этом использовав более длинные временные ряды для расчета рыночной премии за риск по рынку США, может гибридная модель САРМ. Отдельно обратим внимание на то, что использование гибридной модели САРМ для «Уралкалия» обоснованно, так как это российская компания международного масштаба: 90\% продукции экспортируется, 12,75\% акций обращается на LSE, на РTC торги акциями характеризуются очень высокой ликвидностью, а иностранные инвесторы в России предпочитают акции частных эффективно управляемых компаний (таких, как «Уралкалий»).

Модель сочетает элементы глобальной и локальной моделей САРМ: от локальной доходность акций на внутреннем рынке, от глобальной - премия за рыночный риск и безрисковая доходность по рынку США, суверенный спред дефолта, новый элемент - бэта, рассчитанная как ковариация доходностей акций эмитента и международного рыночного портфеля.

Шаг 1. Какова базовая премия за риск (в США)? Сначала определим, на каком временном горизонте будем рассчитывать премию. Некоторые исследователи используют данные не с 1928 года, а за 50, 20 или даже 10 лет, так как считают, что степень склонности к риску инвесторов меняется со временем. Однако в этом случае возрастает стандартная ошибка значений рыночной премии за риск (в $1 /\left(\right.$ число лет) ${ }^{\wedge} 0,5$ раз). Что, на наш взгляд, является очень большой жертвой, поэтому будем рассчитывать за период 1928-2007 годов. На сайте www.damodaran.com приведены значения премии за риск, рассчитанной как среднеарифметическая суммы разностей между рыночной доходностью и государственными долгосрочными облигациями. MRP (USA) $=6,42 \%$. $R_{f}(t-$ bond's in 2007) $=4,88 \%$.

Шаг 2. Рассчитываем ежедневные доходности акций «Уралкалия» и доходности глобального рыночного портфеля, индекса S\&P500, за 2002-2007 годы. (стандартный временной горизонт в 5 лет). Проблему, связанную с отсутствием котировок акций за некоторые дни, решаем с помощью расчета средних между соседними значениями. Beta $=$ $\operatorname{Cov}(\mathrm{Rm} ; \mathrm{Re}) / \operatorname{Var}(\mathrm{Rm})=0,53$.

Шаг 3. Суверенный кредитный рейтинг России на конец 2007 года - Ваa2, спред дефолта соответствует 1,73\% (источник: damodaran.com).

Шаг 4. $R_{\varepsilon}(\$)=4,88 \%+0,53 * 6,42 \%+1,73 \%=10 \%$.

Шаг 5. Оценки рассчитаны на долларовой основе, поэтому, чтобы перейти к рублевым расчетам, необходимо скорректировать на разницу в инфляциях в России $(11,9 \%)$ и США $(4,1 \%)$ по итогам 2007 года. $R_{\varepsilon}=110 * 111,9 / 104,1-100=18,25 \%$

\footnotetext{
Выпуск \#4(8), 2008

(C) Электронный журнал Корпоративные Финансы, 2008
} 
3.4. Гибридная модель оценки капитальных активов с корректировками (Hybrid CAPM with adjustments) [Дамодаран, 2004]

Трудно не согласится с тем, что премия за суверенный риск инвестирования в акции превышает суверенный спред дефолта, который оценивает изменчивость доходности облигаций. Поэтому необходимо скорректировать оценки премии на волатильность фондового рынка акций по сравнению с соответствующим показателем для рынка облигаций. Мы рассчитали волатильность рынка облигаций как стандартное отклонение доходности еврооблигаций Россия-2030 по ежедневным значениям за 2007 год. Соответственно оценили волатильность рынка акций по доходности индекса РТС. Так,

$$
\begin{aligned}
& \text { Суеренныи риск }=0,0138 / 0,0073 * 1,73=3,29 ; \\
& R_{q}(\$)=4,88 \%+0,53 * 6,42 \%+3,29 \%=11,56 \% \\
& R_{g}=111,56 * 111,9 / 104,1-100=19,92 \% .
\end{aligned}
$$

\subsection{Down-side CAРМ [Эстрада, 2003]}

Особенность данного метода расчета требуемой доходности по собственному капиталу заключается в том, что мы учитываем только те значения доходности акций и рыночного индекса, которые меньше среднего за период. Снова используем 5-летний временной горизонт.

$$
\beta_{i}^{D}=\frac{S_{i M}}{S_{M}^{2}}=\frac{E\left\{\operatorname{Min}\left[\left(R_{i}-\mu_{i}\right), 0\right] * \operatorname{Min}\left[\left(R_{M}-\mu_{M}\right), 0\right]\right\}}{E\left\{\operatorname{Min}\left[\left(R_{M}-\mu_{M}\right), 0\right]^{2}\right\}}
$$

Аналогично недостающие значения восстанавливаем, как средние между соседними ежедневными доходностями акций «Уралкалия». Получается, что $\beta^{D}=0,43$. Соответственно $R_{e}=5,76 \%+0,43 * 11 \%=10,43 \%$.

Мы полагаем, что оценки, полученные на основе исторических премий за риск по российским данным, являются неадекватными ввиду малого числа наблюдений и неразвитости финансового рынка. Глобальная модель САРМ вообще не может быть применена из-за очень короткого временного ряда котировок акций «Уралкалия» на международном финансовом рынке. Поэтому наиболее приемлемым подходом является гибридная модель САРМ с использованием страновых рисков. Далее будем в качестве требуемой стоимости по собственному капиталу использовать соответствующее значение, равное $18,25 \%$. 


\section{4. Модели оптимальной структуры капитала}

4.1. Сравнение с конкурентами

Диаграмма 3

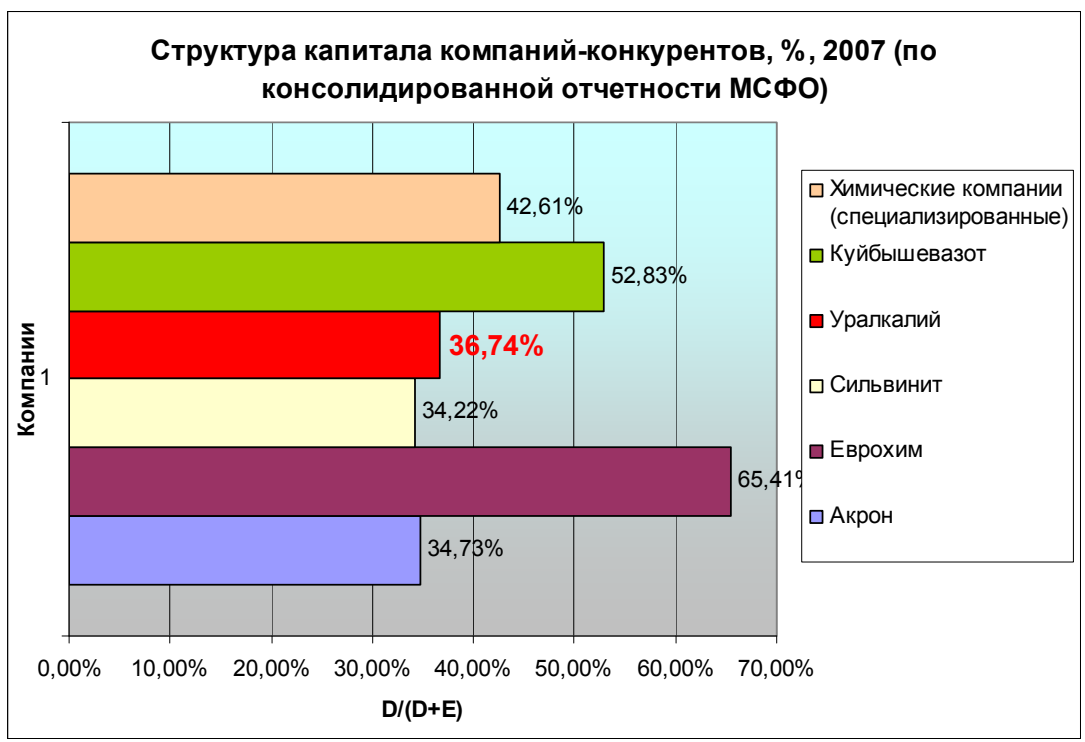

На диаграмме 3 видно, что текущая (все данные приведены за 2007 год) структура капитала ОАО «Уралкалий» представляет среднее между соответствующими значениями компаний-конкурентов. Строго говоря, приведенные компании, за исключением ОАО «Сильвинит», не являются прямыми конкурентами, так как работают в других сегментах химической отрасли. Наиболее адекватный показатель для сравнения - среднемировое соотношение обязательств и активов для специализированных химических компаний: ОАО «Уралкалий» $(36,74 \%)$ занимает меньше, чем в среднем конкуренты по миру $(42,61 \%)$. Сравнение с прямым конкурентом ОАО «Сильвинит» показывает, что компании имеют схожую структуру капитала.

\section{2. Затраты на капитал (WACC)}

Методология модели по шагам:

- В соответствии с уровнем долговой нагрузки поставить кредитный рейтинг (используя данные Дамодаран www.damodaran.com). В таблице ниже приведены рейтинги для крупных производственных компаний.

\section{Таблица 2}

\begin{tabular}{|l|l|l|l|l|l|l|l|l|l|l|l|l|l|l|}
\hline $\begin{array}{l}\text { Interest coverage } \\
\text { ratio larger than }\end{array}$ & 0,2 & 0.65 & 0.8 & 1.25 & 1.5 & 1.75 & 2 & 2.25 & 2.5 & 3 & 4.25 & 5.5 & 6.5 & 8.5 \\
\hline Rating & $\mathrm{D}$ & $\mathrm{CC}$ & $\mathrm{CCC}$ & $\mathrm{B}-$ & $\mathrm{B}$ & $\mathrm{B}+$ & $\mathrm{BB}$ & $\mathrm{BB}+$ & $\mathrm{BBB}$ & $\mathrm{A}-$ & $\mathrm{A}$ & $\mathrm{A}+$ & $\mathrm{AA}$ & $\mathrm{AAA}$ \\
\hline Spread & $20.00 \%$ & $10.00 \%$ & $7.50 \%$ & $6.50 \%$ & $5.65 \%$ & $4.50 \%$ & $3.65 \%$ & $3.20 \%$ & $2.50 \%$ & $1.70 \%$ & $1.50 \%$ & $1.40 \%$ & $1.25 \%$ & $0.75 \%$ \\
\hline
\end{tabular}

- Рассчитать beta unlevered по формуле Хамады:

$\beta_{\text {unievered }}=\beta_{\text {levered }} /(1+(1-$ Income $T a x) * D / E)=0,53 /(1+0,78 * 0,57)$.

- Рассчитать beta levered (чем больше долг, тем больше издержки финансовой неустойчивости, тем большую доходность требуют акционеры) по формуле Хамады для каждого уровня отношения обязательств к активам. 
- Рассчитать требуемую доходность по собственному капиталу по модели Нybrid САРМ (что проделано выше).

- Рассчитать требуемую доходность по заемному капиталу как

$R_{d}=R_{f}+$ Sovereign risk + Defaultspreas, где спред дефолта рассчитан соответственно кредитному рейтингу Damodaran, суверенный спред дефолта составляет 1,73 для России по итогам 2007 года.

- Затраты на капитал

- $\quad W A C C=D /(D+E) *(1-$ Income tax $) * R_{d} \neq E *(D+E) * R_{e}$.

Таблица 3

\begin{tabular}{|l|l|l|l|l|l|l|l|l|l|l|}
\hline Rating & AAA & AAA & AA & A- & BBB & BB & B & B- & CCC & CC \\
\hline D/(D+E) & $0 \%$ & $10 \%$ & $20 \%$ & $30 \%$ & $40 \%$ & $50 \%$ & $60 \%$ & $70 \%$ & $80 \%$ & $90 \%$ \\
\hline D/E & $0 \%$ & $11 \%$ & $25 \%$ & $43 \%$ & $67 \%$ & $100 \%$ & $150 \%$ & $233 \%$ & $400 \%$ & $900 \%$ \\
\hline Beta levered & 0,36 & 0,40 & 0,43 & 0,48 & 0,55 & 0,64 & 0,78 & 1,01 & 1,47 & 2,86 \\
\hline Re & $17,12 \%$ & $17,33 \%$ & $17,59 \%$ & $17,94 \%$ & $18,39 \%$ & $19,03 \%$ & $19,98 \%$ & $21,58 \%$ & $24,77 \%$ & $34,33 \%$ \\
\hline Default Spread & $0,75 \%$ & $0,75 \%$ & $1,25 \%$ & $1,70 \%$ & $2,50 \%$ & $3,65 \%$ & $5,65 \%$ & $6,50 \%$ & $7,50 \%$ & $10,00 \%$ \\
\hline Rd & $7,09 \%$ & $7,84 \%$ & $9,09 \%$ & $10,79 \%$ & $13,29 \%$ & $16,94 \%$ & $22,59 \%$ & $29,09 \%$ & $36,59 \%$ & $46,59 \%$ \\
\hline WACC & $17,12 \%$ & $16,19 \%$ & $15,46 \%$ & $15,01 \%$ & $15,07 \%$ & $15,95 \%$ & $18,30 \%$ & $21,95 \%$ & $27,20 \%$ & $35,30 \%$ \\
\hline
\end{tabular}

На диаграмме 4 представлена зависимость затрат на капитал от структуры капитала, очевидно, что глобальный минимум достигается при $\mathrm{D} /(\mathrm{D}+\mathrm{E})^{*}$, находящемся в интервале от 30 до $40 \%$.

\section{Диаграмма 4}

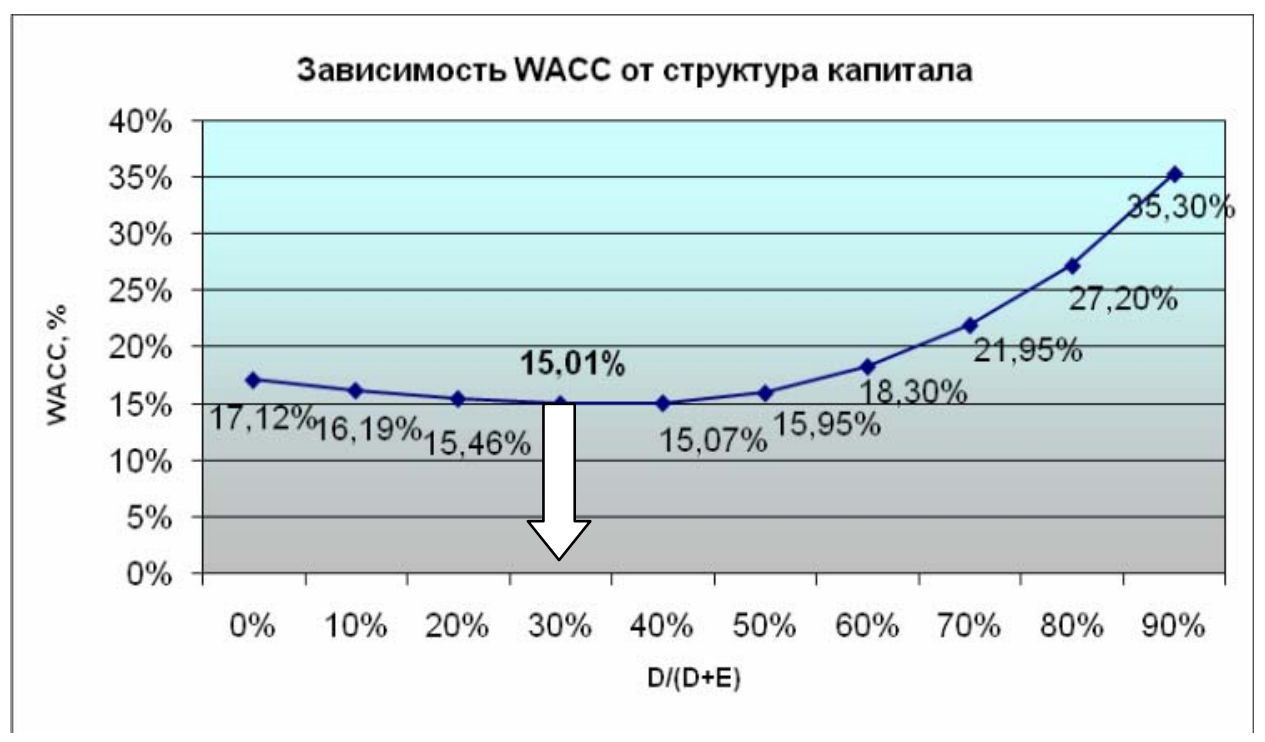

Исходя из этого, можно сказать, что текущая структура капитала ОАО «Уралкалий» очень близка к оптимальной.

\section{3. Операционная прибыль (Operating income) [Майерс, 1974]}

Суть метода заключается в том, что мы оцениваем вероятность дефолта компании (невозможность погасить проценты по долгу) в зависимости от структуры капитала.

Методология модели по шагам:

- В соответствии с уровнем долговой нагрузки поставить кредитный рейтинг (используя данные Дамодаран www.damodaran.com), согласно которому определяется 
коэффициент покрытия процентов.

- Рассчитываем стандартное отклонение ЕВIT по историческим значениям за 20012007 годы, так как прогнозы менеджмента «Уралкалия» относительно будущих денежных потоков найти в открытых источниках не удалось. S.e. (EBIT) $=3527,92$. Понятно, что увеличение количества наблюдений или с помощью использования месячных данных, или с помощью использования прогнозов сможет уменьшить величину стандартной ошибки.

Таблица 4

\begin{tabular}{|l|l|l|l|l|l|l|l|}
\hline & 2001 & 2002 & 2003 & 2004 & 2005 & 2006 & 2007 \\
\hline ЕВІТ, млн. руб. & 1374,35 & 1622,49 & 1372,01 & 3838,93 & 9896,07 & 5368,50 & 8571,43 \\
\hline
\end{tabular}

- Рассчитываем t-статистику $=($ EBIT-Interest paid)/s.e.EBIT с 6 степенями свободы, где количество степеней свободы равно количеству наблюдений минус 1.

Таблица 5

\begin{tabular}{|l|l|l|l|l|l|l|l|l|l|l|}
\hline Rating & AAA & AAA & AA & A- & BBB & BB & B & B- & CCC & CC \\
\hline $\mathrm{D} /(\mathrm{D}+\mathrm{E})$ & $0 \%$ & $10 \%$ & $20 \%$ & $30 \%$ & $40 \%$ & $50 \%$ & $60 \%$ & $70 \%$ & $80 \%$ & $90 \%$ \\
\hline $\mathrm{D} / \mathrm{E}$ & $0 \%$ & $11 \%$ & $25 \%$ & $43 \%$ & $67 \%$ & $100 \%$ & $150 \%$ & $233 \%$ & $400 \%$ & $900 \%$ \\
\hline $\begin{array}{l}\text { Interest Cover- } \\
\text { age Ratio }\end{array}$ & 8.5 & 8.5 & 6.5 & 3.0 & 2.5 & 2.0 & 1.5 & 1.3 & 0.8 & 0.7 \\
\hline EBIT & 11647 & 11647 & 11647 & 11647 & 11647 & 11647 & 11647 & 11647 & 11647 & 11647 \\
\hline Interest & 0.00 & 1370.24 & 1791.85 & 3882.33 & 4658.80 & 5823.50 & 7764.67 & 9317.60 & 14558.75 & 17918.46 \\
\hline t-статистика & 3.30 & 2.91 & 2.79 & 2.20 & 1.98 & 1.65 & 1.10 & 0.66 & -0.83 & -1.78 \\
\hline P-Value & $0.00 \%$ & $2.69 \%$ & $3.14 \%$ & $7.00 \%$ & $9.49 \%$ & $14.99 \%$ & $31.33 \%$ & $53.36 \%$ & $100.00 \%$ & $100.00 \%$ \\
\hline
\end{tabular}

На диаграмме 5 представлена зависимость вероятности дефолта от структуры капитала. Понятно, что при уровне долговой нагрузки больше 80\% коэффициент покрытия процентов становится меньше 1 , следовательно, вероятность дефолта $=100 \%$.

\section{Диаграмма 5}

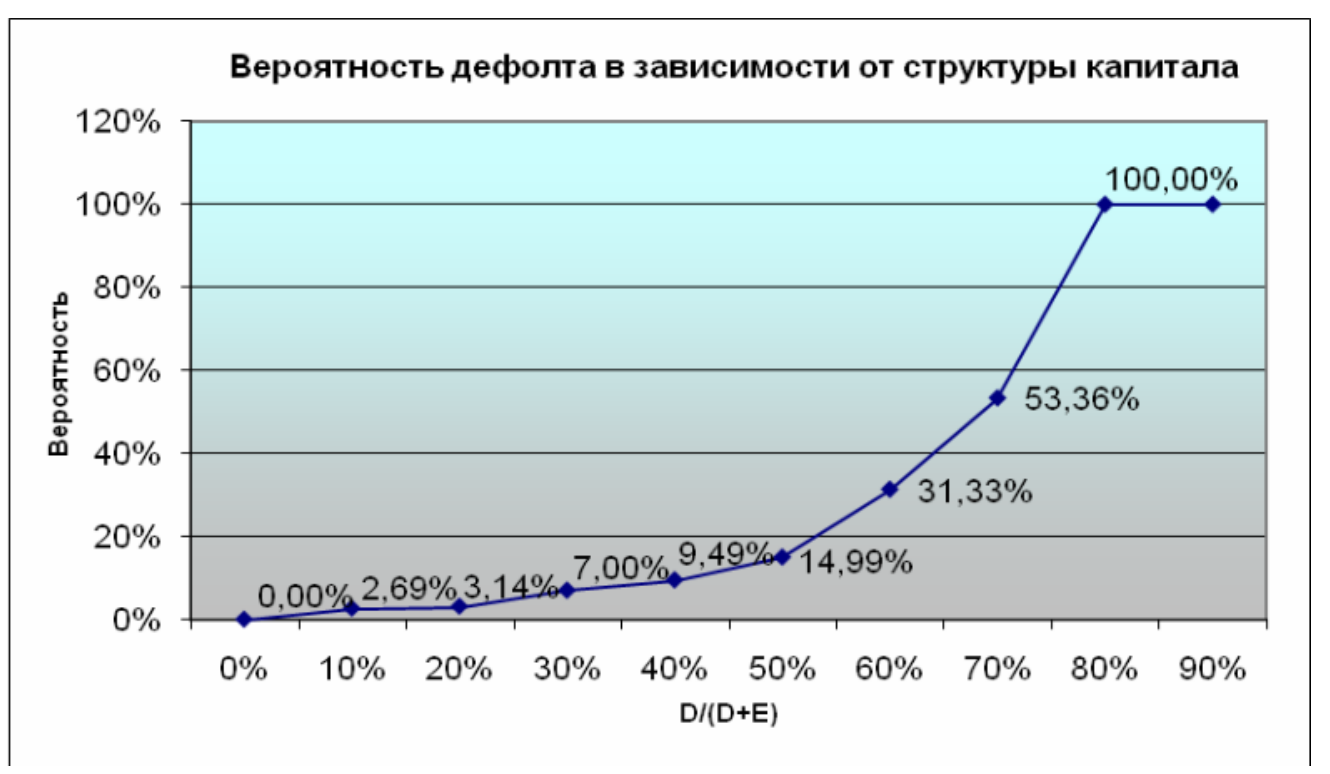


4.4. Скорректированная приведенная стоимость (Adjusted present value) [Mайерс, 1974]

В модели предполагается, что наращивание долговой нагрузки позволяет экономить на налоге на прибыль, при возрастании издержек финансовой неустойчивости по сравнению со стоимостью компании без долгового финансирования.

$$
V_{\text {levered }}=V_{\text {unlevered }}+P V(T a x \text { Shield })-P V(\text { Bankruptcy Cost })
$$

Шаг 1. Сначала рассчитаем стоимость компании без долгов с помощью модели дисконтированных денежных потоков. Так как информации в открытых источниках о планируемых денежных потоках «Уралкалия» найти не удалось, мы решили в модели DCF спрогнозировать 5\%-ный темп роста на бесконечность (компания в долгосрочном периоде не сможет расти быстрее мировой экономики) и использовать в качестве ставки дисконтирования ранее рассчитанную требуемую доходность по собственному капиталу $R_{e}=17,12 \%$.

\section{Таблица 6}

\begin{tabular}{|l|l|l|l|l|l|l|l|}
\hline EBIT & EBIT*(1-Tax $)$ & Depreciation & Capex & NWC & FCF & Interest expense & FCFE \\
\hline 11647 & 8851,72 & 1976 & 6120 & 1243 & 3464,72 & 723 & 2741,72 \\
\hline
\end{tabular}

Шаг 2. Рассчитаем приведенную стоимость налогового щита, как произведение долга и ставки по корпоративному налогу.

Шаг 3. Рассчитаем приведенную стоимость издержек финансовой неустойчивости, как произведение ранее рассчитанной вероятности дефолта и двух стандартных отклонений EBIT.

Таблица 7

\begin{tabular}{|l|l|l|l|l|l|l|l|l|l|l|}
\hline Rating & AAA & AAA & AA & A- & BBB & BB & B & B- & CCC & CC \\
\hline D/(D+E) & $0 \%$ & $10 \%$ & $20 \%$ & $30 \%$ & $40 \%$ & $50 \%$ & $60 \%$ & $70 \%$ & $80 \%$ & $90 \%$ \\
\hline Debt & 0 & 3963,5 & 7927 & 11890,5 & 15854 & 19817,5 & 23781 & 27744,5 & 31708 & 35671,5 \\
\hline PVTS & 0 & 951,24 & 1902,48 & 2853,72 & 3804,96 & 4756,2 & 5707,44 & 6658,68 & 7609,92 & 8561,16 \\
\hline 2 s.e. EBIT & 7055,84 & 7055,84 & 7055,84 & 7055,84 & 7055,84 & 7055,84 & 7055,84 & 7055,84 & 7055,84 & 7055,84 \\
\hline Probability & $0,00 \%$ & $2,69 \%$ & $3,14 \%$ & $7,00 \%$ & $9,49 \%$ & $14,99 \%$ & $31,33 \%$ & $53,36 \%$ & $100,00 \%$ & $100,00 \%$ \\
\hline PVBC & 0,00 & 189,63 & 221,79 & 494,00 & 669,71 & 1057,62 & 2210,67 & 3764,92 & 7055,84 & 7055,84 \\
\hline V levered & 22621,45 & 23383,06 & 24302,14 & 24981,17 & 25756,71 & 26320,03 & 26118,22 & 25515,21 & 23175,53 & 24126,77 \\
\hline
\end{tabular}

Максимум стоимости достигается при значении показателя $\mathrm{D} /(\mathrm{D}+\mathrm{E})^{*}=50 \%$. 


\section{Диаграмма 6}

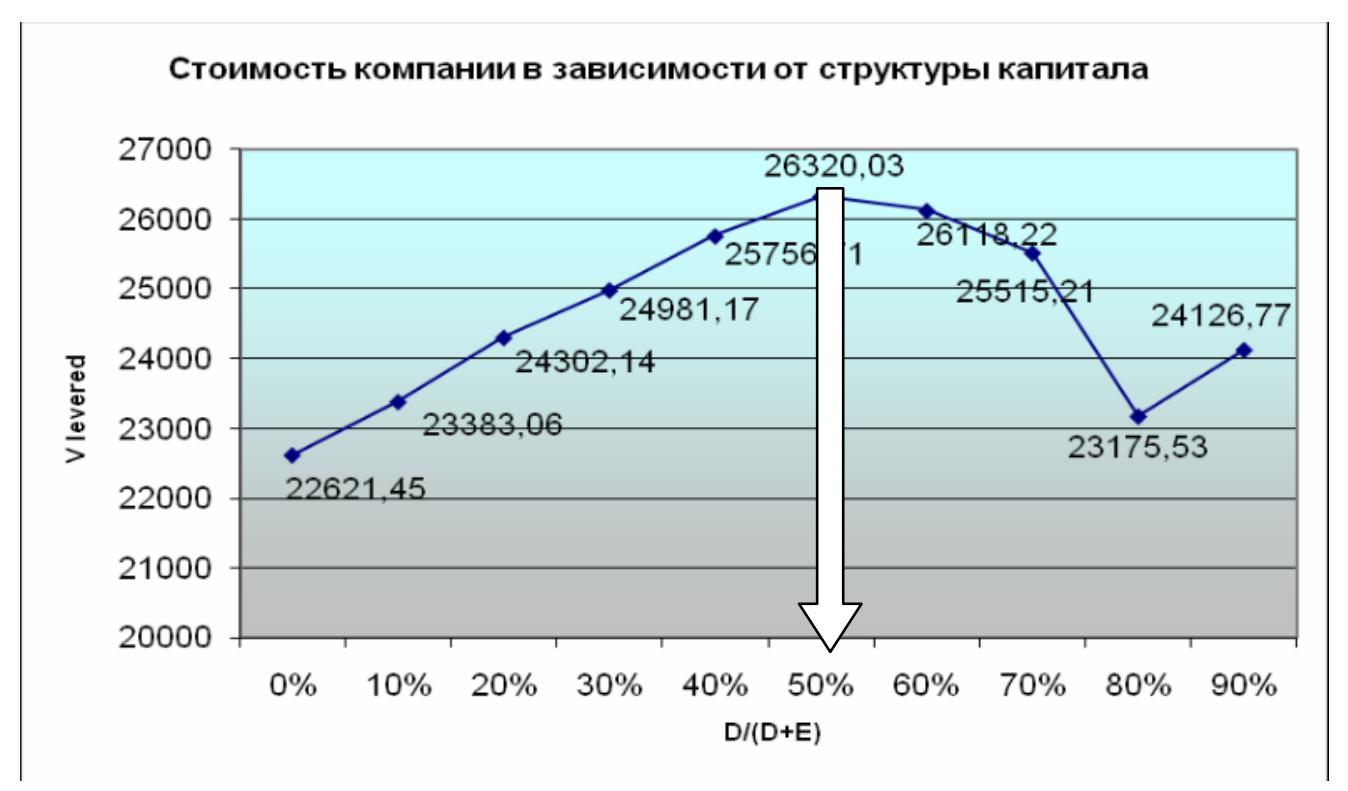

Мы считаем, что у модели APV в данном исследовании большой недостаток, связанный с сомнительной статистической значимостью стандартной ошибки ЕВIT на основе всего семи исторических наблюдений (за 2001-2007 годы). Поэтому подводить итоги об оптимальности текущей структуры капитала будем по результатам модели WACC и сравнения с конкурентами.

\section{5. Сравнение с зарубежным конкурентом Kali\&Salz AG (Кассель, Германия)}

\section{1. Основные характеристики:}

- Специализация - производство калийных удобрений.

- Выпускает около 10\% мирового объема калийных удобрений.

- Объединяет все производственные активы немецкой калийной отрасли.

- Имеет производственные активы в других странах Европы и в Южной Америке.

- Собственники: Андрей Мельниченко - 10,73\%, BASF - 10\%, остальное - free float.

- В индексе средних предприятий MDAX - c 1998 года, в главном индексе DAX - c 2008-го.

Немецкая орпорация Kali\&Salz AG весьма похожа на «Уралкалий» как по виду деятельности, мировой рыночной доле, структуре собственности, так и по динамике капитилизации. 


\section{Диаграмма 7}

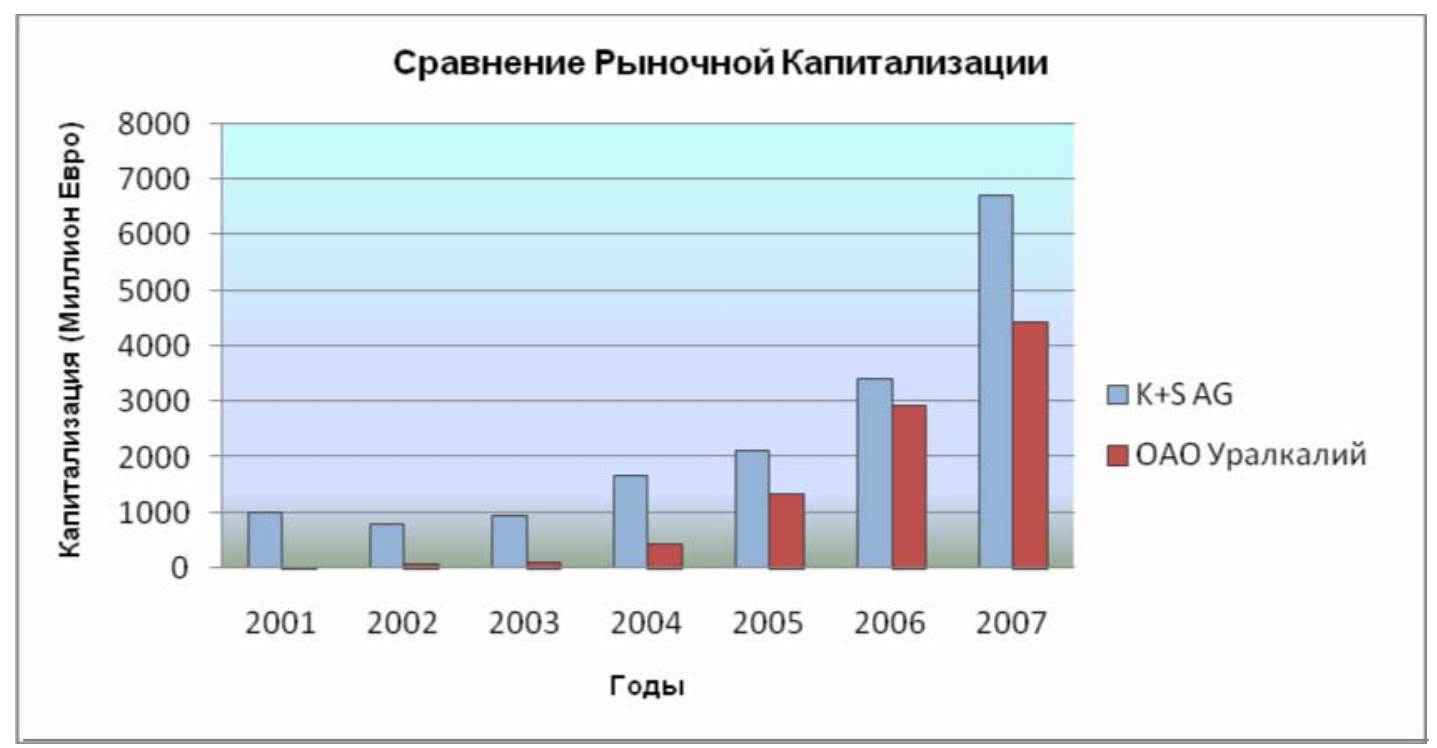

Однако отношение обязательств к активам Kali\&Salz AG, рассчитанное по балансовой стоимости, существенно превышает соответствующий показатель для «Уралкалий», что представлено на Диаграмме 8.

\section{Диаграмма 8}

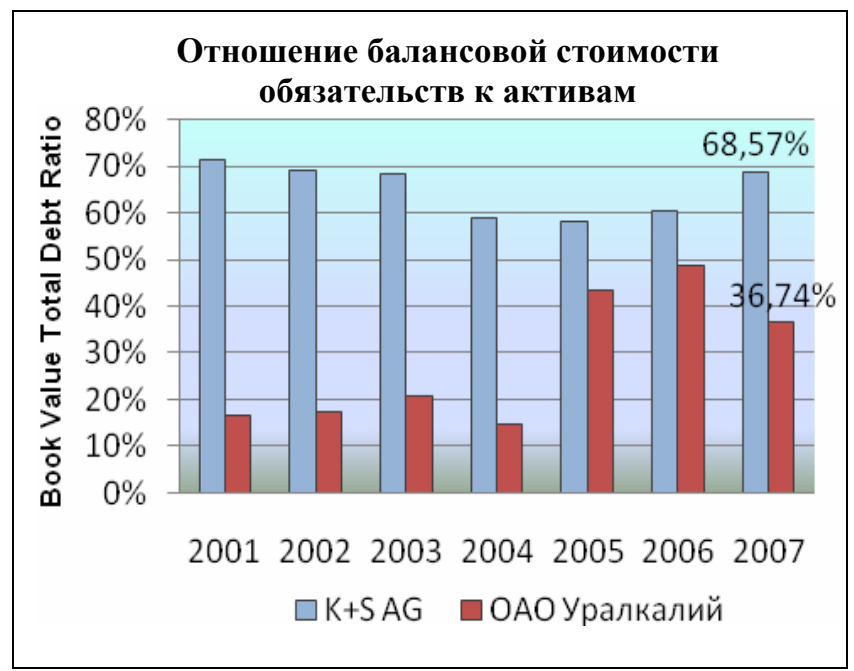

На диаграмме 9 ниже видно, что различные балансовые показатели Kali\&Salz AG превышают соответствующие показатели «Уралкалия» приблизительно в 2 раза, а рыночные - почти в 3. 


\section{Диаграмма 9}

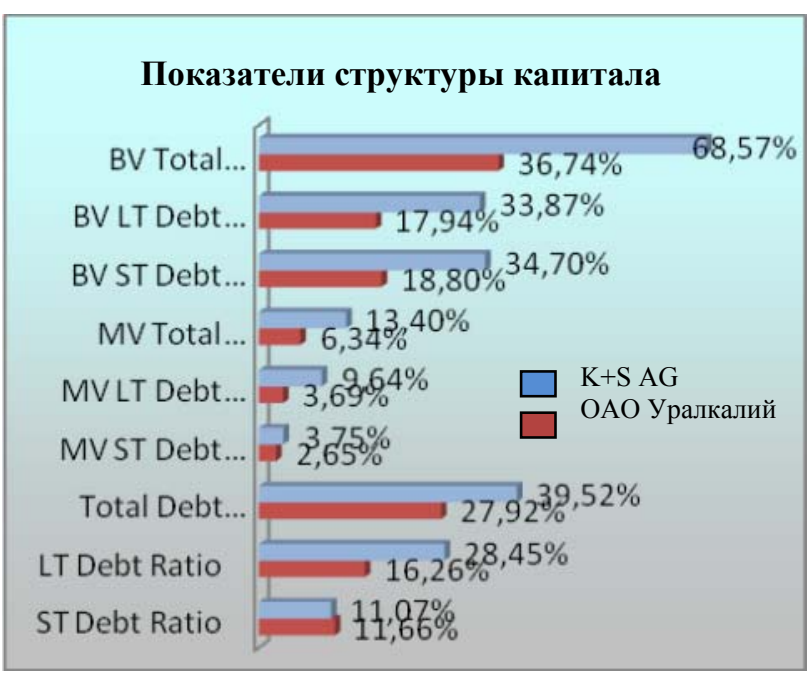

\section{2. Затраты на капитал (WACC)}

Аналогично приведенной выше методологии рассчитаем затраты на капитал. Все основные показатели взяты из годового отчета за 2007 год Kali\&Salz AG:

- Безрисковая ставка $=4,8 \%$ (Euro-Composite Index с рейтингом «ААA» на 30-летний срок).

- Рыночная премия за риск $=4.5 \%$ (индекс MSCI Europe).

- Бэта unlevered $=0,72$.

- Спред дефолта Германии = спред дефолта США = 0 (источник: www.damodaran.com).

Таблица 8

\begin{tabular}{|l|l|l|l|l|l|l|l|l|l|l|}
\hline Credit Rating & AAA & AAA & AA & A- & BBB & BB & B & B- & CCC & CC \\
\hline D/E & $0 \%$ & $11 \%$ & $25 \%$ & $43 \%$ & $67 \%$ & $100 \%$ & $150 \%$ & $233 \%$ & $400 \%$ & $900 \%$ \\
\hline D/(D+E) & $\mathbf{0} \%$ & $\mathbf{1 0} \%$ & $\mathbf{2 0} \%$ & $\mathbf{3 0} \%$ & $\mathbf{4 0} \%$ & $\mathbf{5 0} \%$ & $\mathbf{6 0} \%$ & $\mathbf{7 0} \%$ & $\mathbf{8 0} \%$ & $\mathbf{9 0 \%}$ \\
\hline Default Spread & $0,75 \%$ & $0,75 \%$ & $1,25 \%$ & $1,70 \%$ & $2,50 \%$ & $3,65 \%$ & $5,65 \%$ & $6,50 \%$ & $7,50 \%$ & $10,00 \%$ \\
\hline Cost of Debt Pretax & $5,55 \%$ & $5,55 \%$ & $6,05 \%$ & $6,50 \%$ & $7,30 \%$ & $8,45 \%$ & $10,45 \%$ & $11,30 \%$ & $12,30 \%$ & $14,80 \%$ \\
\hline Tax Rate & $28 \%$ & $28 \%$ & $28 \%$ & $28 \%$ & $28 \%$ & $28 \%$ & $28 \%$ & $28 \%$ & $28 \%$ & $28 \%$ \\
\hline Cost of Debt Posttax & $4,00 \%$ & $4,00 \%$ & $4,36 \%$ & $4,68 \%$ & $5,26 \%$ & $6,08 \%$ & $7,52 \%$ & $8,14 \%$ & $8,86 \%$ & $10,66 \%$ \\
\hline Risk-Free Rate & $4,80 \%$ & $4,80 \%$ & $4,80 \%$ & $4,80 \%$ & $4,80 \%$ & $4,80 \%$ & $4,80 \%$ & $4,80 \%$ & $4,80 \%$ & $4,80 \%$ \\
\hline Beta levered & 0,72 & 0,78 & 0,85 & 0,94 & 1,07 & 1,24 & 1,50 & 1,93 & 2,80 & 5,39 \\
\hline Market Risk-Premium & $4,50 \%$ & $4,50 \%$ & $4,50 \%$ & $4,50 \%$ & $4,50 \%$ & $4,50 \%$ & $4,50 \%$ & $4,50 \%$ & $4,50 \%$ & $4,50 \%$ \\
\hline Cost of Equity & $8,04 \%$ & $8,30 \%$ & $8,63 \%$ & $9,05 \%$ & $9,60 \%$ & $10,38 \%$ & $11,55 \%$ & $13,50 \%$ & $17,39 \%$ & $29,07 \%$ \\
\hline WACC & $\mathbf{8 , 0 4} \%$ & $\mathbf{7 , 8 7} \%$ & $\mathbf{7 , 7 7 \%}$ & $\mathbf{7 , 7 4 \%}$ & $\mathbf{7 , 8 6} \%$ & $\mathbf{8 , 2 3} \%$ & $\mathbf{9 , 1 3 \%}$ & $\mathbf{9 , 7 4 \%}$ & $\mathbf{1 0 , 5 6 \%}$ & $\mathbf{1 2 , 5 0 \%}$ \\
\hline
\end{tabular}

Глобальный минимум функции затрат на капитал достигается при значении отношения обязательств к активам компании в интервале от 20 до $30 \%$. 


\section{Диаграмма 10}

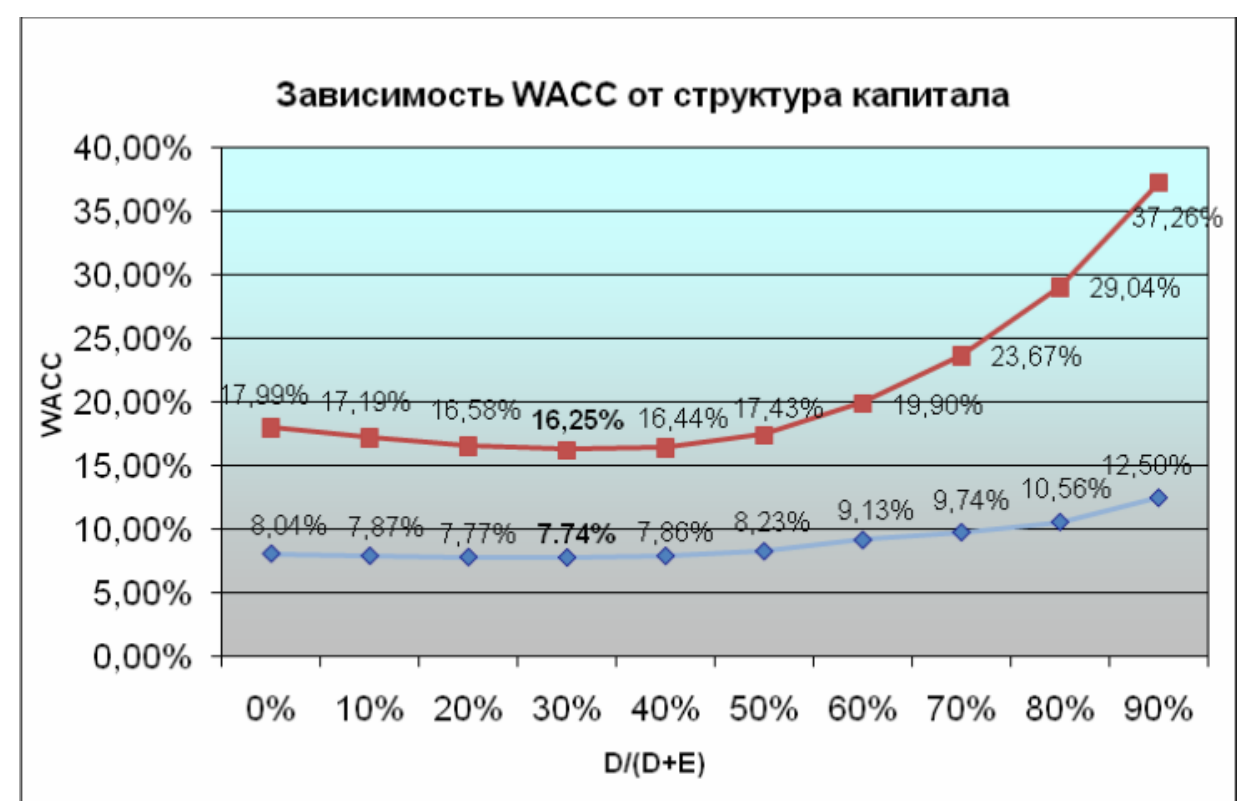

Очевидно, что затраты на капитал в России значительно выше, чем в Германии. В первую очередь это зависит от значительного различия в уровнях инфляции (по итогам 2007 года она составила в России - $11,7 \%$ в Германии - 3\%). К тому же России присущ значительный страновой риск: спред дефолта для российских компаний составляет 1,73\%, для немецких - 0\%. Кроме того, необходимо заметить, что кривая затрат на капитал Kali\&Salz AG является более плоской, что снова связано с меньшим спредом дефолта в Германии.

\section{3. Операционная прибыль (Operational income)}

Мы считаем, что польза модели операционной прибыли для компании Kali\&Salz AG сомнительна, потому что ожидаемый показатель ЕВIT почти в 5 раз превышает значения прибыли за последние 10 лет. Поэтому историческое отклонение, скорее всего, не очень показательно для будущего развития.

\section{Диаграмма 11}

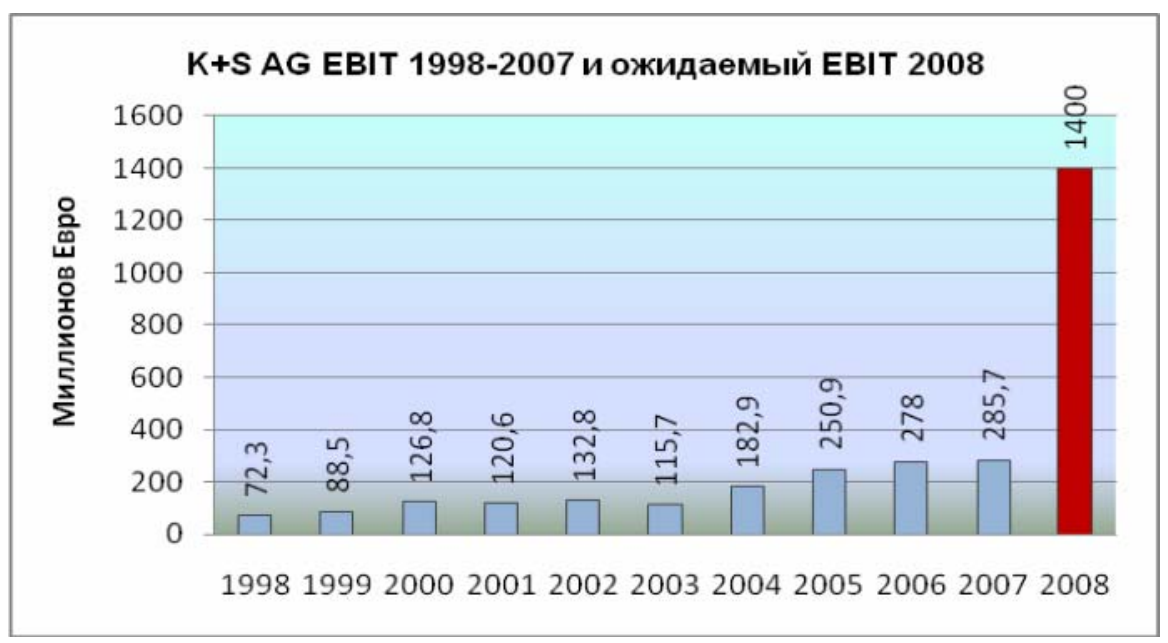

Мы использовали вышеуказанную методологию для расчета вероятности дефолта и 
пришли к выводу, что вероятность дефолта Kali\&Salz AG для каждого значения отношения обязательств к активам немного ниже соответствующего показателя «Уралкалия». Но как уже сказано, значение этого результата со статистической точки зрения достаточно сомнительно.

\section{Диаграмма 12}

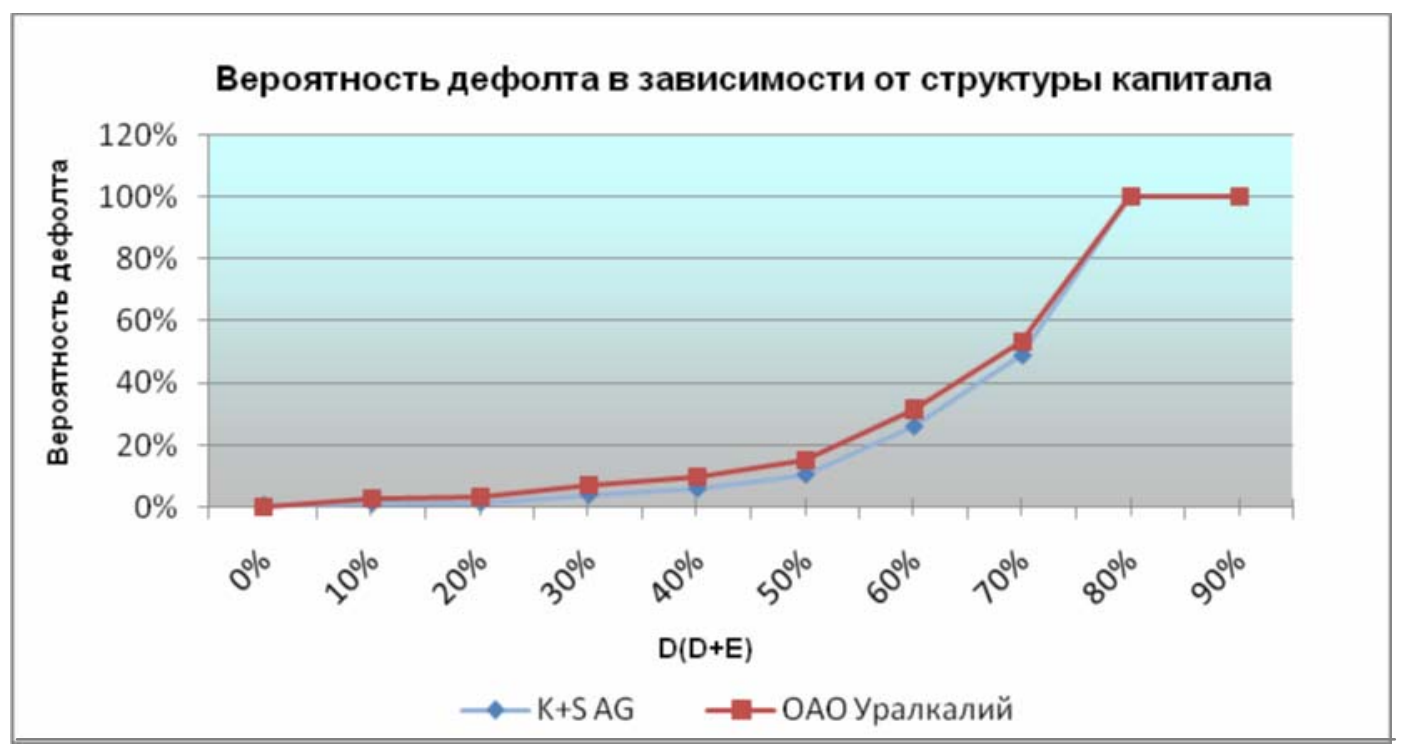

5.4. Скорректированная приведенная стоимость (Adjusted present value)

Расчет скорректированной приведенной стоимости компании начинаем с вычисления стоимости Kali\&Salz AG без долгов с помощью модели дисконтированных денежных потоков. Так как информации в открытых источниках о планируемых денежных потоках Kali\&Salz AG найти не удалось, мы решили в модели DCF спрогнозировать 4\%-ный темп роста на бесконечность и использовать в качестве ставки дисконтирования ранее рассчитанную требуемую доходность по собственному капиталу $\operatorname{Re}=7,93 \%$.

Таблица 9

\begin{tabular}{|l|l|l|l|l|l|l|l|}
\hline EBIT & EBIT*(1-Tax) & Depreciation & Capex & $\Delta$ NWC & FCF & Interest Paid & FCFE \\
\hline 285,70 & 205,71 & 128,21 & 171,60 & $-33,30$ & 195,62 & 24,30 & 171,32 \\
\hline
\end{tabular}

Таблица 10

\begin{tabular}{|l|l|l|l|l|l|l|l|l|l|l|}
\hline Credit Rating & AAA & AAA & AA & A- & BBB & BB & B & B- & CCC & CC \\
\hline D/(D+E) & $0 \%$ & $10 \%$ & $20 \%$ & $30 \%$ & $40 \%$ & $50 \%$ & $60 \%$ & $70 \%$ & $80 \%$ & $90 \%$ \\
\hline Debt & 0,0 & 296,5 & 593,0 & 889,4 & 1185,9 & 1482,4 & 1778,9 & 2075,4 & 2371,8 & 2668,3 \\
\hline Tax Rate & $28 \%$ & $28 \%$ & $28 \%$ & $28 \%$ & $28 \%$ & $28 \%$ & $28 \%$ & $28 \%$ & $28 \%$ & $28 \%$ \\
\hline PVTS & 0,0 & 83,0 & 166,0 & 249,0 & 332,1 & 415,1 & 498,1 & 581,1 & 664,1 & 747,1 \\
\hline Default Probability & $0,00 \%$ & $1,11 \%$ & $1,37 \%$ & $3,95 \%$ & $5,85 \%$ & $10,46 \%$ & $25,96 \%$ & $48,87 \%$ & $100,00 \%$ & $100 \%$ \\
\hline 2 S.D. EBIT & 158,3 & 158,3 & 158,3 & 158,3 & 158,3 & 158,3 & 158,3 & 158,3 & 158,3 & 158,3 \\
\hline PVBC & 0,0 & 1,8 & 2,2 & 6,2 & 9,3 & 16,6 & 41,1 & 77,4 & 158,3 & 158,3 \\
\hline PV of levered firm & $\mathbf{4 3 5 9 , 3}$ & $\mathbf{4 4 4 0 , 6}$ & $\mathbf{4 5 2 3 , 2}$ & $\mathbf{4 6 0 2 , 1}$ & $\mathbf{4 6 8 2 , 1}$ & $\mathbf{4 7 5 7 , 9}$ & $\mathbf{4 8 1 6 , 3}$ & $\mathbf{4 8 6 3 , 1}$ & $\mathbf{4 8 6 5 , 2}$ & $\mathbf{4 9 4 8 , 2}$ \\
\hline
\end{tabular}


Диаграмма 13

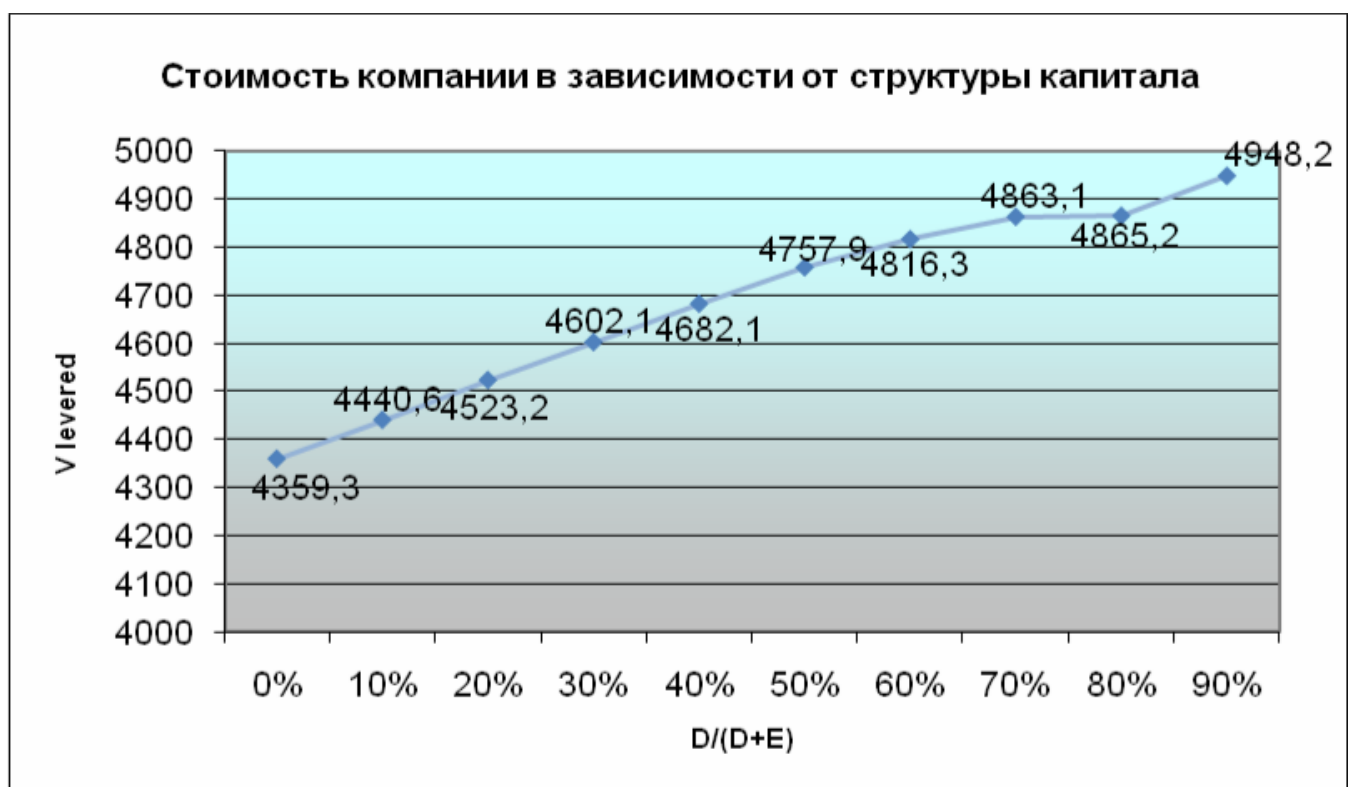

График зависимости стоимости компании Kali\&Salz AG от структуры капитала показывает, что наибольшее значение стоимости достигается при $100 \%$-ной долговой нагрузке, что, очевидно, не соответствует действительности, да и, вообще говоря, абсурдно. Причиной служит неадекватный показатель стандартного отклонения EBIT, по которому рассчитаны издержки финансовой неустойчивости. Получается, что издержки занижены, а стоимость монотонно возрастает с ростом долговой нагрузки. Поэтому подводить итоги об оптимальности текущей структуры капитала будем по результатам модели WACC: компания Kali\&Salz AG заимствует (на конец 2007 года отношение совокупных обязательств к активам составляло 68,57\%) значительно больше оптимального уровня, который, по нашим расчетам, составляет от 20 до $30 \%$.

\section{Post-case (динамика структуры капитала ОАО «Уралкалий» в 2008 году, после периода наблюдения)}

На основании промежуточной финансовой отчетности (по стандартам МСФО) за 1-е полугодие 2008 года ОАО «Уралкалий» известно, что отношение обязательств к активам снизилось до $35,2 \%$, что связано с увеличением на $39 \%$ нераспределенной прибыли (для сравнения: обязательства выросли на 30\%).

\section{Заключение}

Мы ставили перед собой задачу определить оптимальную структуру капитала ОАО «Уралкалий» на 31.12.07. Использовав ряд современных моделей, мы пришли к выводу, что ОАО «Уралкалий» имеет структуру капитала, близкую к оптимальной: компания находится немного «левее» оптимума на оси отношения совокупных обязательств к активам, что объясняется достаточно просто. Издержки снижения финансового рычага для возвращения к оптимуму зачастую существенно превышают недополученную стоимость, связанную с недозаимствованием при малых отклонениях от оптимального значения, так как достаточно резко возрастают издержки финансовой неустойчивости.

Кроме того, мы сравнили оптимальную структуру капитала ОАО «Уралкалий» с немецким конкурентом, корпорацией Kali\&Salz AG. Оказалось, что оптимальное отношение обязательств к активам немецкой корпорации несколько меньше соответствующего показателя для российской компании: максимум стоимости Kali\&Salz AG достигается при 
уровне отношения совокупных обязательств к активам в интервале от 20 до 30\%, максимум стоимости «Уралкалия» - от 30 до 40\%. Такое различие, вероятно, объясняется межстрановыми различиями в требуемой доходности по собственному капиталу, при схожих значениях требуемой доходности по заемному капиталу с точностью до суверенного спреда дефолта, исходя из результатов модели затрат на капитал (WACC). Хотя, безусловно, наше предположение о большей значимости межстрановых, нежели межфирменных, различий требует более серьезного регрессионного анализа для подвтерждения данной гипотезы.

\section{Список литературы}

1. Дамодаран А. Инвестиционная оценка. Инструменты и методы оценки любых активов. М.: Альпина Бизнес Букс, 2004.

2. Estrada J. Systematic Risk in Emerging Markets: the D-CAPM. / Emerging Markets Review. 2002.

3. Lintner J. The valuation of risk assets and selection of risky investments in stock portfolio and capital budgets / Review of economics and statistics. Vol. 47. 1965. pp. 13-37.

4. Myers S. Interactions of Corporate Financing and Investment Decisions-Implications for Capital Budgeting / The Journal of Finance. Vol. 29. 1974. pp.1-25.

5. Sharpe W.F. Capital Asset Prices: A Theory of Market Equilibrium under Conditions of Risk / Journal of Finance. Vol. 19. 1964. pp. 425-442.

6. Stulz R. Globalisation, corporate finance, and the cost of capital / Journal of Applied Corporate Finance. Vol. 12. 1999. pp. 8-25.

7. www.damodaran.com 